\title{
NEW RECORD OF COCHLIOBOS HAWAIIENSIS ALCORN ASSOCIATED WITH BUTTON SHEDDING AND PREMATURE NUTFALL IN COCONUT IN INDIA
}

\author{
By \\ A. KARTHIKEYAN \& R. BIL4SKARAN ${ }^{1}$
}

\begin{abstract}
SUMMARY
From the shed buttons and immature nuts of coconut, a jungus was isolated which on artificial inoculation in coconut bunches of varying ages caused button shedding and premature nutfall. The fungus was identified as Cochliobolus hawaiiensis Alcorn. Buttons up to 4 months age were susceptible to the fungus. Among the thirteen coconut genotypes studied, infection was high in Lakshadweep Micro, Lakshadweep Ordinary an d East Coast Tall x Malaysian Green Dwarf (ECT x MGD). Carboxin 75 WP (500 ppm and above), mancozeb and copper oxy chloride (1000 ppm and above) completely inhibited the mycelial growth of $C$ hawaiiensis under in vitro conditions. In Vivo, mancozeb $(0.2 \%)$ was very effective for the control of the disease.
\end{abstract}

\section{INTRODUCTION}

Button shedding and premature nutfall in coconut (Cocos nucifera L. is caused by several factors viz. genetic variability, physiological or environmental conditions, fertilization, excessive soil moisture and drought, nutritional deficiency, diseases and pests (Sudhakara, 1990).

Fungi as one of the major causes of button shedding has been reported by many workers. Mac Donald (1924) observed in Kenya that the falling of buttons and nuts was due to infection of flowers with Colletotrichum sp which caused gumming of tissues at the point of their attachment va'th the inflorescence. Simmods (1924) found that shedding of buttons was associated with the infestation of the fungus Botryodiplodia. The fungus Phytophthora sp as the cause of button shedding has been reported from Sri Lanka (Gadd, 1922) and India (Sunderaraman and Ramakrishnan, 1924). Diseases caused by Phytophthora palmivora (Sunderaraman and Krishnaswami, 1933), Botryosphaeria rhodina (SuRathmath and Shantappa, 1979), Ganoderma lucidum (Bhaskaran et al., 1989) and G. boninense (Ohler, 1984) also cause button shedding in coconut. Aspergillus, Penicillium Phytophthora, Fusarium, Choanepheora cucurbitarum and Pestalotia have also been reported to be associated with button shedding (Anonymous, 1988). In the present paper, button shedding caused by Cochliobolus hawaiiensis Alcorn., a new record of this fungus on coconut is reported.

\section{MATERIALS AND METHODS}

A study was conducted at the Coconut Research Station, Veppankulam to assess the extent of button shedding and premature nutfall and nuts to infection by the pathogen(s). Total number of buttons in each bunch after one month of spathe opening was counted for six consecutive months in each tree and number of buttons and immature nuts shed due to fungal infection were counted every month. Fresh shed buttons and immature nuts from different genotypes were collected, examined under the microscope and isolations were made in potato dextrose agar medium to assess the extent of pathological causes of button shedding.

${ }^{1}$ Asst. Professor, Plant Pathology, Coconut Research Station, Tamil Nadu and Professor of Plant Pathology, Agricultural College and Research Institute, Tamil Nadu, India, respectively. 
Seven fungicides, viz., carbendazim, carboxmi, tridemorph, copper oxy chloride, Bordeaux mixture, mancozeb and ziram at three different concentrations were tested under in vitro conditions for their efficacy against $\mathrm{C}$ hawahensis, the pathogen causing shedding and premature nutfall in coconut. The effective fungicides were tested under field conditions in ECT coconut palms for the control of the diseases.

\section{RESULTS AND DISCUSSION}

Button shedding due to fungal infection was high in the genotypes Lakshadweep Micro (LM), Laksahdweep Ordinary (LO) and ECT x Malayan Green Dwarf Buttons up to 4 months age alone are infected by fungi and there was no button shedding due to fungal infection after 4th month (Table 1).

\section{Fungi Associated}

Three fungal isolates viz., Aspergillus sp., Penicillium sp., and a graminicolus funtms were consistently obtained from shed buttons and immature nuts. On articificial inoculation, Aspergillus sp and Penicillium sp failed to infect either the shed buttons or inunature nuts and buttons in coconut bunches. The granunicolus fungus was identified as Cochhobolus hawahensis Alcom. by International Mycological Institute, Kew, Surrey (IMI) 354567). (C. hawahensis Alcom. has been recorded for the first time in India in coconut). Buttons and immature nuts of 1 to 4 months old of ECT variety were artificially inoculated vrith the fungus in the stalk end. The growth of fungus was observed within 5 days after inoculation and an area of about, $3-4 \mathrm{~cm}$ radius around the point of inoculation was covered by the fungus within 20 days after inoculation resulting in shedding of buttons and immature nuts from 10th to 25th day after inoculation depending upon the age of the buttons.

\section{Control}

Mancozeb and copper oxy chloride at 1000, 2000 and 3000 ppm and carboxin at 500, 1000 and $2000 \mathrm{ppm}$ concentrations completely inhibited the growth of $C$ hawahensis under in vitro conditions. Ziram at $3000 \mathrm{ppm}$ concentration gave $66.5 \%$ inhibition. Under field condition mancozeb at $0.2 \%$ concentration gave $74.2 \%$ reduction in the disease incidence followed by carboxin (56.5\%) and copper oxy chloride (48.4\%) when compared to control (Table 2).

\section{CONCLUSION}

Pathological causes of button shedding assume significant proportions during the recent years. $C$. hawaiiensis has been isolated for the first time from coconut and its role in button shedding and pre-mature nutfall in coconut was established. Fungicide spray at the correct time will help to reduce loss caused by the fungi.

\section{ACKNOWLEDGMENT}

The authors arc thankful to Dr. A. Sivanesan, International Mycological Institute, London for his help in the identification of the 


\section{REFERENCES}

ANONYMOUS, 1988. Studies on button shedding and immature nutfall in coconut. Annual Report for 1986. Central Plantation Crops Research Institute, Kasaragod, India. pp. 55

BHASKARAN, R., RETHINAM P. and NAMBIAR, K.K.N. 1999 Thanjavur wilt of coconut. J. Plan. Crops 17. p. 69-79.

GADD, C.H. 1922. Nutfall in coconuts. Dept. Agric. Ceylon. Bulletin, p. 53

MAC DONALD, 1924. Ann. Rep. Kenya, Dept. Agric. pp. 106-111

OHLER. J.G. 1994. Coconut, Tree of Life. FAO Plant Production and Protection paper 57, Rome p. 446

SIMMONDS, H.W. 1924. Mission to New Guinea Bismarks, Solomon and New Helerido, Legis. Council. Paper No. 22, Fiji

SUDHAKARA, K. 1990. Button shedding and premature nutfall in coconut. J. Plant. Crops. 18 pp. 66-77.

SULLADMATH, V.V. and SHANTAPPA, R.B. 1979, Nutfall in coconut associated with Botiyosphaeria rhodina. (Berk \& Curt) V.Arx. Current Research 19. p. 13.

SUNDERARAMAN, S. and KRISHNASWAMI, C.S. 1933. Fungoid diseases of important crops in Madras presidency. Bulletin No.32 of the Madras Department of Agriculture.

SUNDERARAMAN, S. and RAMAKRISHNAN, T.S. 1924. The Mahali diseases of coconut in Malabar. Menip. Dep. Apric. India. Bot. Ser. 13. pp. 97-97 
Table 1: Incidence of button shedding and premature nutfall in different Coconut genotypes due to fungal infection

\begin{tabular}{|l|c|c|c|c|c|c|}
\hline \multirow{3}{*}{ Genotypes } & \multicolumn{7}{|c|}{ Age of buttons (months) } \\
\cline { 2 - 7 } & $\begin{array}{c}\text { No. of shed } \\
\text { buttons/palm } \\
\text { s 6 mos }\end{array}$ & 1 & 2 & 3 & 4 & Total \\
\hline ECT & 90 & $20.00^{*}$ & 12.00 & 8.00 & 1.78 & 41.78 \\
& & $(26.17)$ & $(20.10)$ & $(16.23)$ & $(7.49)$ & \\
\hline WCT & 80 & 20.00 & 15.00 & 5.00 & 0.00 & 40.00 \\
& & $(26.32)$ & $(22.74)$ & $(12.79)$ & $(14.54)$ & \\
\hline LO & 88 & 18.18 & 27.27 & 9.10 & 0.00 & 54.55 \\
& & $(25.19)$ & $(31.46)$ & $(17.50)$ & $(14.54)$ & \\
\hline LM & 176 & 45.45 & 22.73 & 11.36 & 0.00 & 79.54 \\
& & $(42.38)$ & $(28.43)$ & $(19.61)$ & $(14.54)$ & \\
\hline Zanzibar & 40 & 20.00 & 0.00 & 0.00 & 0.00 & 20.00 \\
& & $(26.45)$ & $(14.54)$ & $(14.54)$ & $(14.54)$ & \\
\hline ECT X MGD & 72 & 27.78 & 11.11 & 3.33 & 1.11 & 43.33 \\
& & $(31.76)$ & $(19.27)$ & $(10.45)$ & $(5.89)$ & \\
\hline ECT X MYD & 64 & 25.00 & 6.25 & 3.75 & 1.25 & 36.25 \\
& & $(29.95)$ & $(14.40)$ & $(11.11)$ & $(6.19)$ & \\
\hline WCT X COD & 100 & 28.00 & 0.00 & 0.80 & 0.00 & 28.80 \\
& & $(31.91)$ & $(14.54)$ & $(5.11)$ & $(14.54)$ & \\
\hline LM X MGD & 112 & 25.00 & 14.29 & 0.00 & 0.00 & 39.29 \\
& & $(30.00)$ & $(22.14)$ & $(14.54)$ & $(14.54)$ & \\
\hline ECT X Ay & 100 & 12.00 & 8.00 & 0.00 & 12.00 & 32.00 \\
& & $(20.14)$ & $(16.28)$ & $(14.54)$ & $(19.92)$ & \\
\hline Ay X COD & 96 & 16.64 & 25.00 & 0.00 & 0.00 & 41.67 \\
& & $(24.07)$ & $(29.95)$ & $(14.54)$ & $(14.54)$ & \\
\hline Cochin China & 52 & 23.08 & 0.00 & 0.00 & 0.00 & 23.08 \\
X Philippines & & $(28.61)$ & $(14.54)$ & $(14.54)$ & $(14.54)$ & \\
\hline C.D. (P = 0.05) & 7.46 & 3.16 & 2.39 & 1.66 & 2.05 & \\
\hline
\end{tabular}

\section{LEGEND}

ECT - East Coast Tall WCT - West Coast Tall LO - Lakshadweep Ordinary

LM - Lakshadweep Micro
MYD - Malaysian Yellow Dwarf COD - Chowgat Orange Dwarf Ay - Ayiramkachi

MGD - Malaysian Green Dwarf

- - Percent shed buttons due to fungal infection

Data in parenthesis are aresin transformed values. 
Table 2: Efficacy of fungicides against $\mathrm{C}$. hawaiiensis under in vitro conditions

\begin{tabular}{|c|c|c|c|}
\hline & $\begin{array}{l}\text { Concentration } \\
\text { (ppm) Diameter }\end{array}$ & $\begin{array}{ll}\text { Colony } & \\
& \text { Inhibition } \\
\end{array}$ & $\begin{array}{l}\text { Percent } \\
\text { Over control }\end{array}$ \\
\hline \multirow[t]{3}{*}{ Carbendazim 50WP } & 500 & 4.60 & 40.00 \\
\hline & 1000 & 4.33 & 43.6 \\
\hline & 2000 & 3.40 & 55.7 \\
\hline \multirow[t]{3}{*}{ Bordeaux mixture } & 5000 & 4.77 & 37.8 \\
\hline & 7500 & 4.60 & 40.0 \\
\hline & 1000 & 4.00 & 47.9 \\
\hline \multirow{3}{*}{ Tridemorph $80 \mathrm{EC}$} & 1000 & 4.26 & 44.5 \\
\hline & 2000 & 3.23 & 57.9 \\
\hline & 3000 & 3.03 & 60.5 \\
\hline \multirow[t]{3}{*}{ Mancozeb $45 \mathrm{WP}$} & 1000 & 0.00 & 100.0 \\
\hline & 2000 & 0.00 & 100.0 \\
\hline & 3000 & 0.00 & 100.0 \\
\hline \multirow[t]{3}{*}{ Carboxin $75 \mathrm{WP}$} & 500 & 0.00 & 100.0 \\
\hline & 1000 & 0.00 & 100.0 \\
\hline & 2000 & 0.00 & 100.0 \\
\hline \multirow{3}{*}{$\begin{array}{l}\text { Copper oxychloride } \\
50 \mathrm{WP}\end{array}$} & 1000 & 0.00 & 100.0 \\
\hline & 2000 & 0.00 & 100.0 \\
\hline & 3000 & 0.00 & 100.0 \\
\hline \multirow[t]{3}{*}{ Ziram $27 \mathrm{SC}$} & 1000 & 3.60 & 53.1 \\
\hline & 2000 & 3.00 & 60.9 \\
\hline & 3000 & 2.57 & 66.5 \\
\hline \multirow{2}{*}{$\begin{array}{l}\text { Control } \\
\text { C.D }(P=0.05)\end{array}$} & - & 7.67 & - \\
\hline & & 0.16 & \\
\hline
\end{tabular}

Table 2a: Efficacy of fungicides against $\mathrm{C}$. hawaiiensis under in vivo conditions

\begin{tabular}{|l|r|r|r|}
\hline Carbendazim 75 WP & 0.1 & 5.4 & 56.5 \\
\hline $\begin{array}{l}\text { Copper oxy chloride } \\
\text { 50 WP }\end{array}$ & 0.3 & 6.4 & 48.4 \\
\hline Mancozeb 45 WP & & & 74.2 \\
\hline Ziram 27 SC & 0.2 & 3.2 & 30.7 \\
\hline Control & 0.3 & 8.6 & - \\
\hline C.D $(\mathrm{P}=0.05)$ & - & 12.4 & 3.5 \\
\hline
\end{tabular}

